\title{
Resveratrol inhibits canonical Wnt signaling in human MG-63 osteosarcoma cells
}

\author{
YONGGEN ZOU $^{1 *}$, JIEXIANG YANG $^{2^{*}}$ and DIANMING JIANG ${ }^{1}$ \\ ${ }^{1}$ Department of Orthopedics, The First Affiliated Hospital of Chongqing Medical University, Chongqing 400016; \\ ${ }^{2}$ Department of Orthopedics, Affiliated Traditional Chinese Medicine Hospital of Luzhou Medical College, \\ Luzhou, Sichuan 646000, P.R. China
}

Received August 20, 2014; Accepted June 5, 2015

DOI: $10.3892 / \mathrm{mmr} .2015 .4338$

\begin{abstract}
In the last 30 years, the 5-year-survival rate of patients with osteosarcoma has not improved as a result of the low prevalence and large tumor heterogeneity. Therefore, the development of novel drugs for the treatment of osteosarcoma is urgently required. The present study aimed to identify potential novel drugs for the treatment of osteosarcoma, thus used $\beta$-catenin as a target and performed high content screening. In a total of 14 botanical extracts assessed, resveratrol markedly downregulated the expression of $\beta$-catenin and significantly inhibited MG-63 cell proliferation. CCK-8 assay was used to confirm the anti-osteosarcoma effect of resveratrol and flow cytometry and western blotting were performed to analyze the underlying mechanisms of the proapoptotic effects of resveratrol. $\beta$-catenin is a vital member of the canonical Wnt signaling pathway and, therefore, the target genes of this pathway were further analyzed. The results of this analysis demonstrated that resveratrol suppressed the MG-63 cells by inhibiting the canonical Wnt signaling pathway.
\end{abstract}

\section{Introduction}

Osteosarcoma (OS) is a rare malignancy deriving from primitive transformed cells of mesenchymal origin (1). It is ranked among the leading causes of cancer-associated mortality in the pediatric age group in the USA $(2,3)$. Following the introduction of chemotherapy in the $1970 \mathrm{~s}$, the 5-year-survival rate has increased by $\sim 50 \%$ (4). However, it is difficult to obtain meaningful progression in patient survival rates as a result of the low prevalence and large tumor heterogeneity of OS (2).

Correspondence to: Dr Dianming Jiang, Department of Orthopedics, The First Affiliated Hospital of Chongqing Medical University, 1 Yixueyuan Road, Chongqing 400016, P.R. China E-mail: jdm571026@vip.163.com

${ }^{*}$ Contributed equally

Key words: osteosarcoma, Wnt signaling pathway, $\beta$-catenin, high content screening
Therefore, in vitro preclinical screening is a vital element in OS drug investigations.

The canonical Wnt signaling pathway is important in cancer progression and embryonic development. Mutations, which promote constitutive activation of the Wnt signaling pathway, lead to cancer (5). For example, familial adenomatous polyposis is caused by truncations in adenomatous polyposis coli, which promotes aberrant activation of the Wnt pathway $(6,7)$. Mutations in $\beta$-catenin have also been identified in a variety of tumor types (8). Loss-of-function mutations in Axin have been found in hepatocellular carcinoma (9). Therefore, tight control of the Wnt signal pathway is essential in preventing cancer.

$\beta$-catenin is a pivotal molecule in the Wnt signaling pathway, which is a dual function protein that regulates the coordination of cell-cell adhesion and gene transcription (10). Gain-of-function mutations in $\beta$-catenin leads to cancer, owing to the aberrant activation of target genes of the Wnt signaling pathway $(11,12)$. The protein level of $\beta$-catenin in the cytoplasm is maintained accurately through phosphorylation/degradation. Mutations in $\beta$-catenin result in amino acid substitution, which affects the phosphorylation level of $\beta$-catenin. Consequently, incorrectly phosphorylated $\beta$-catenin is not recognized by the E3 ubiquitin ligase, $\beta$-Trcp, which targets $\beta$-catenin for proteasomal degradation (13). Dysregulation of Wnt signaling pathways allows $\beta$-catenin to accumulate and translocate into the nucleus, where it activates oncogenes (14-17). Therefore, $\beta$-catenin is a potential drug target for the treatment of cancer. It has been demonstrated that $\beta$-catenin exhibits higher levels of expression in mesenchymal tumors (18).

Resveratrol is a natural product derived from grapes and has been reported to have cancer chemopreventive activity (19). Previous studies focused on its anti-tumor activities and have demonstrated that it has potent antiproliferative effects on tumor cells, causes cell cycle arrest and promotes apoptosis (20-22). The potential mechanism was suggested to be associated with the ERKs/p53 cascade or caspase-3-dependent pathway $(22,23)$. However, whether the anti-OS effect of resveratrol is associated with Wnt signaling remains to be elucidated.

In the present study, cellomics high content screening was performed to identify a novel potential drug for the treatment of OS. 


\section{Materials and methods}

Cell culture. The human MG-63 OS cell line (Type Culture Collection of the Chinese Academy of Sciences, Shanghai, China) was cultured in Eagle's minimum essential medium (Gibco Life Technologies, Grand Island, NY, USA), supplemented with $1 \%$ non-essential amino acids, $10 \%$ fetal bovine serum, $100 \mathrm{U} / \mathrm{ml}$ penicillin (Sigma-Aldrich, St. Louis, MO, USA) and $100 \mu \mathrm{g} / \mathrm{ml}$ streptomycin (Sigma-Aldrich), and incubated at $37^{\circ} \mathrm{C}$ with $5 \% \mathrm{CO}_{2}$ in a humidified incubator.

High content screening. A total of $\sim 5 \times 10^{2}$ cells were seeded into each well of a 96 -well plate and incubated at $37^{\circ} \mathrm{C}$ with $5 \% \mathrm{CO}_{2}$ in a humidified incubator. Following incubation for $24 \mathrm{~h}$, the botanical extracts (diosmin, lemon bioflavonoids, neosperidin dihydrochalcone, Melissa rosemary acid, oleanolic acid, tartaric acid, ellagic acid, neohesperidin, phillyrin, betaine anhydrous, panax quinquefolium saponin, paeoniflorin, solanesol and resveratrol) that were purchased from Dalian Zhuoer Hightechnology Co., Ltd. (Dalian, China) were added and incubated for $48 \mathrm{~h}$. The final concentration of each botanical extract was $10 \mu \mathrm{g} / \mathrm{ml}$. Finally, the expression of $\beta$-catenin in the MG-63 cells treated with botanical extract was assessed by immunofluorescent staining. In brief, the cells were fixed with $-20^{\circ} \mathrm{C}$ methyl alcohol for $20 \mathrm{~min}$. Following 10 min of natural drying, the cells were washed with phosphate-buffered saline (PBS) three times, $0.2 \%$ Triton X-100 (Sinopharm Chemical Reagent Co., Ltd., Shanghai, China) was used for cell permeabilization ( $3 \mathrm{~min}$ ). Following an additional wash with PBS, the samples were sealed with 5\% bovine serum albumin (BSA; Beyotime Institute of Biotechnology, Shanghai, China) at room temperature for $30 \mathrm{~min}$. The monoclonal rabbit anti-human anti- $\beta$-catenin primary antibody (1:400; ab32572; Abcam, Cambridge, MA, USA) was diluted in $1 \%$ BSA, added into the samples and incubated at $4^{\circ} \mathrm{C}$ overnight. The next day, polyclonal bovine anti-rabbit aminomethylcoumarin-coupled secondary antibodies (IgG; 1:4,000; Wuhan Amyjet Scientific Co., Ltd., Wuhan, China) were added for another $30 \mathrm{~min}$ of incubation in the dark. The samples were washed with PBS three times and sealed with 95\% glycerinum (Sinopharm Chemical Reagent Co., Ltd.), then observed and photographed under a $\times 100$ magnification using a fluorescence microscope (TFM-680; Shanghai Tuming Optical Instrument Co., Ltd., Shanghai, China).

Cell counting kit (CCK)-8 assay to determine cell proliferation. The cells were seeded into a 96-well plate at a density of $5 \times 10^{2}$ cells/well in $100 \mu \mathrm{l}$ culture medium. The cells were cultured for $24 \mathrm{~h}$ at $37^{\circ} \mathrm{C}$ in $5 \% \mathrm{CO}_{2}$ in a humidified incubator. The botanical extract, resveratrol, was added to the cells at a final concentration of 10,20 or $40 \mu \mathrm{g} / \mathrm{ml}$. Following treatment for $24,48,72$ or $96 \mathrm{~h}$ at $37^{\circ} \mathrm{C}, 100 \mu \mathrm{l} \mathrm{CCK}-8$ solution (Dojindo Molecular Technologies, Inc., Kumamoto, Japan) was added into the culture well and the cells were incubated for $4 \mathrm{~h}$ at $37^{\circ} \mathrm{C}$ with $5 \% \mathrm{CO}_{2}$ in a humidified incubator. Following incubation, the supernatant was discarded and $200 \mu 1$ dimethyl sulfoxide was added and incubated for $5 \mathrm{~min}$ on an oscillator (HZP-250; Shanghai Jinghong Laboratory Equipment Co., Ltd.). Finally, the optical density at $450 \mathrm{~nm}\left(\mathrm{OD}_{450}\right)$ was measured using a microplate reader (iMark Model 680; Bio-Rad Laboratories,
Inc., Hercules, CA, USA) and a cell growth curve was produced.

Flow cytometry for cell apoptosis analysis. The Annexin V/fluorescein isothiocyanate (FITC) apoptosis detection kit (Beyotime Institute of Biotechnology) was used to detect cell apoptosis, as previously described (24). The cells were harvested subsequent to treatment with resveratrol alone or in combination with the GSK3 $\beta$ inhibitor chir99021, which was used to investigate whether resveratrol may target the Wnt signal pathway, and a single cell suspension was prepared using trypsin ( $0.25 \%$; Gibco-BRL, Grand Island, NY, USA). The samples were washed with PBS, and subsequently, centrifuged at $157 \mathrm{x} \mathrm{g}$ and $4^{\circ} \mathrm{C}$ for $5 \mathrm{~min}$. The cells were resuspended in binding buffer (BD Biosciences, San Diego, CA, USA), which consisted of $10 \mathrm{mM}$ HEPES/ $\mathrm{NaOH}, \mathrm{pH}$ 7.4, $140 \mathrm{mM} \mathrm{NaCl}$ and $5 \mathrm{mM} \mathrm{CaCl}_{2}$, and the cell density was adjusted to $5 \times 10^{5}$ cells $/ \mathrm{ml}$. A $95-\mu 1$ aliquot of the cell suspension was mixed with $5 \mu \mathrm{l}$ Annexin V-FITC prior to incubation in the dark at room temperature for $10 \mathrm{~min}$. Subsequently, the suspension was washed with PBS and resuspended in $190 \mu \mathrm{l}$ binding buffer, $10 \mu \mathrm{l}$ propidium iodide (PI; Sigma-Aldrich) was added. The samples were examined using a flow cytometer (BD FACSVantage; BD Biosciences) with a $488 \mathrm{~nm}$ excitation source. The test wavelength was set at $515 \mathrm{~nm}$ for FITC and $560 \mathrm{~nm}$ for PI. The results were analyzed using CellQuest software (version 5.2.1; BD Biosciences) to determine apoptosis rate.

Western blotting. The total protein from the cells was extracted using radioimmunoprecipitation lysis buffer, containing $1 \mathrm{mM}$ phenylmethylsulfonyl fluoride (Sinopharm Chemical Reagent Co., Ltd.), and the concentration was determined using the Bradford Assay kit (Beyotime Institute of Biotechnology), according to the manufacturer's instructions. The protein sample $(20 \mu \mathrm{g})$ was separated on $10 \%$ SDS-PAGE gels (Life Technologies, Gaithersburg, MD, USA) and was subsequently transferred onto nitrocellulose membrane (Sigma-Aldrich). The membrane was blocked in PBS, containing Tween-20 (PBST) and 5\% non-fat milk for $1 \mathrm{~h}$ at $4^{\circ} \mathrm{C}$. The membrane was subsequently incubated in primary monoclonal rabbit anti-human antibodies from Abcam against c-Myc (1:100; ab32072), $\beta$-catenin (1:400; ab32572) and GAPDH (1:4,000; ab181602), for $12 \mathrm{~h}$ at $4^{\circ} \mathrm{C}$. Following antibody incubation, the membrane was washed three times with PBST and incubated for 30 min at $4^{\circ} \mathrm{C}$ with the goat anti-rabbit polyclonal secondary antibody (dilution 1:5,000; Beijing Boer Xi Technology Co., Ltd., Beijing, China) labeled with horseradish peroxidase. Finally, the membrane was washed three times with PBST and the protein bands were visualized with SuperSignal (Pierce Biotechnology, Inc., Rockford, IL, USA). The membranes were re-probed with a monoclonal rabbit anti-human $\beta$-actin antibody (1:1,000; A2066; Sigma-Aldrich) as a loading control at $37^{\circ} \mathrm{C}$

Reverse transcription-quantitative polymerase chain reaction $(R T-q P C R)$. The total RNA was extracted from the tissue/cells using TRIzol reagent (Invitrogen Life Technologies, Carlsbad, CA, USA). The total RNA $(0.5 \mu \mathrm{g})$ was used as a template to prepare the cDNA in a $10 \mu$ l reaction, which included $1 \mu \mathrm{l}$ 
A

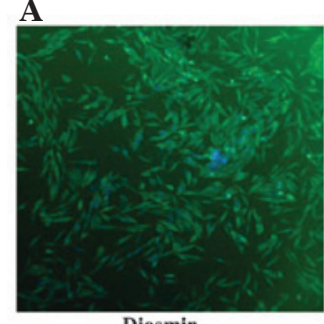

Diosmin

F

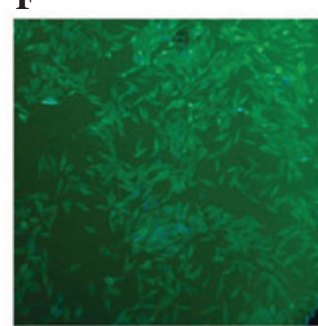

Tartaric acid

K

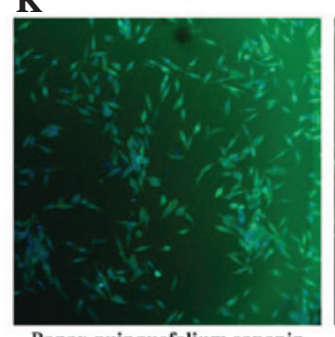

B

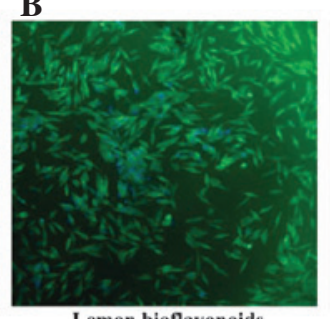

Lemon bioflavonoids

G

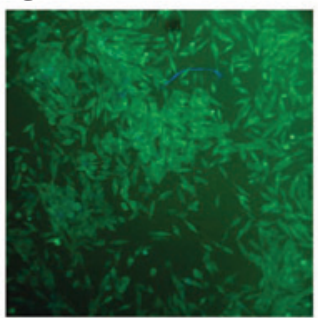

Ellagic acid

L

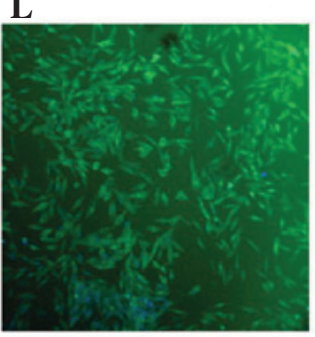

C

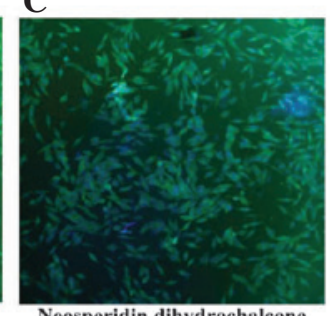

Neosperidin dihydrochalcone

H

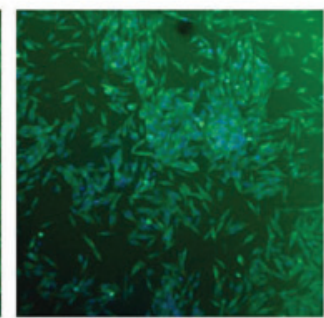

Neohesperidin

M

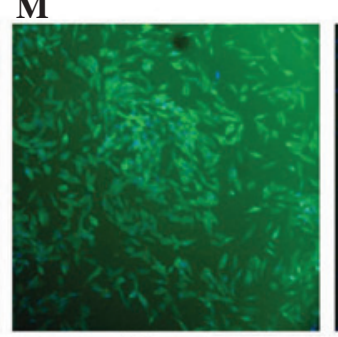

D

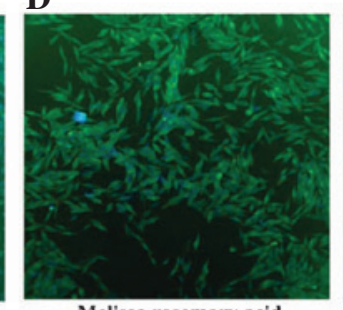

Melissa rosemary acid

I

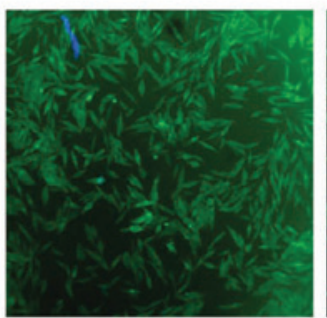

Phillyrin

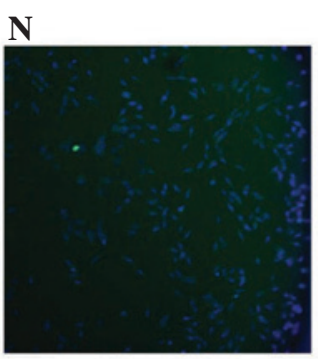

Resveratrol

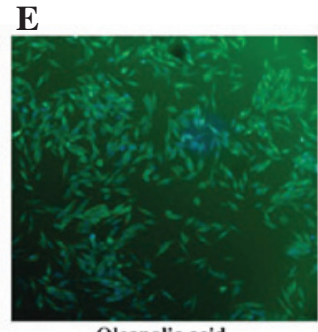

Oleanolic acid

J

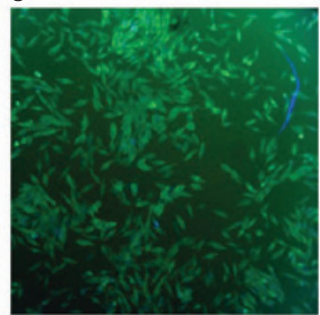

Betaine anhydrous

O

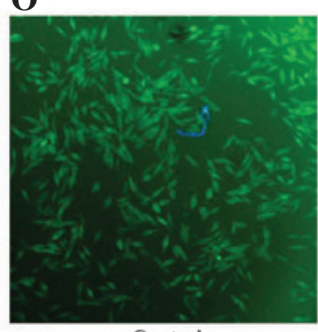

Figure 1. Resveratrol downregulates the protein expression of $\beta$-catenin in human MG-63 osteosarcoma cells. A total of 14 botanical extracts (20 $\mu \mathrm{g} / \mathrm{ml}) \mathrm{were}$ examined by immunofluorescent staining and a fluorescence microscope, at a magnification of x100: (A) Diosmin, (B) Lemon bioflavonoids, (C) Neosperidin dihydrochalcone, (D) Melissa rosemary acid, (E) Oleanolic acid, (F) Tartaric acid, (G) Ellagic acid, (H) Neohesperidin, (I) Phillyrin, (J) Betaine anhydrous, (K) Panax quinquefolium saponin, (L) Paeoniflorin, (M) Solanesol, (N) Resveratrol and an (O) untreated control. Following drug treatment for 48 h, immunofluorescence staining was performed to determine changes in the expression of $\beta$-catenin in the MG- 63 cells.

(50 $\mu \mathrm{M})$ Oligo d (T), $0.5 \mu \mathrm{l} \mathrm{dNTP}$ mixture (10 mM of each; Takara, Bio, Inc., Otsu, Japan), $0.25 \mu 1$ RNase inhibitor (40 U/ $\mu 1$, Takara, Bio, Inc.) and $0.5 \mu \mathrm{l}$ RTase M-MLV (200 U/ $\mu \mathrm{l}$; Takara, Bio, Inc.). The reaction conditions were as follows: $42^{\circ} \mathrm{C}$ for $1 \mathrm{~h}$, followed by $85^{\circ} \mathrm{C}$ for $5 \mathrm{sec}$. The cDNA was diluted five-fold and was used as the PCR template. A SYBR ${ }^{\circledR}$ Premix Ex $\mathrm{Taq}^{\mathrm{TM}}$ kit (Takara, Bio, Inc.) was used to detect gene expression and was performed using a PCR system (qTOWER 2.2, Analytik Jena, Jena, Germany), according to the manufacturer's instructions. Briefly, $2 \mu \mathrm{l}$ cDNA was added to reaction system with $10 \mu \mathrm{l} \mathrm{SYBR}{ }^{\circledR}$ Premix Ex Taq (2X), $0.4 \mu 1$ PCR primer mixture $\left(10 \mu \mathrm{M}\right.$ each) and $7.6 \mu \mathrm{l} \mathrm{dH}_{2} \mathrm{O}$. The primer sequences from Sangon Biotech Co., Ltd. (Shanghai, China) used were as follows: $\beta$-catenin, forward 5'-TTCGCACAGTTCTACGTG CT-3' and reverse 5'-GGTGTGCACGAACAAGCAAT-3'; c-Myc forward 5'-CTTCTCTCCGTCCTCGGATTCT-3' and reverse 3'-GAAGGTGATCCAGACTCTGACCTT-3'; $\beta$-actin forward 5'-GCACCACACCTTCTACAA-3' and reverse 5'-TGC TTGCTGATCCACATCTG-3'. The cycling conditions were as follows: $95^{\circ} \mathrm{C}$ for $30 \mathrm{sec}$; 40 cycles of $95^{\circ} \mathrm{C}$ for $5 \mathrm{sec}$ and $60^{\circ} \mathrm{C}$ for $30 \mathrm{sec}$; followed by a melting curve stage in which the temperature increased from $60-95^{\circ} \mathrm{C}$ at a rate of $5^{\circ} \mathrm{C} / \mathrm{sec}$. The actin gene was used as a control to normalize the relative expression levels of the target gene. The $2^{-\Delta \Delta C t}$ method was performed to calculate the relative expression of the target gene (25).
Statistical analysis. All data are presented as the mean \pm standard deviation. Statistical analysis of the data was performed using Student's t-test with SPSS software, version 19.0 (IBM SPSS, Armonk, NY, USA). P<0.01 was considered to indicate a statistically significant difference.

\section{Results}

High content screening. $\beta$-catenin is one of the members of the canonical Wnt signaling pathway. The dysregulation of the canonical Wnt signaling pathway has been demonstrated in a variety of tumors. In order to screen for drugs, which effectively inhibit the expression of $\beta$-catenin, high content screening was performed in the human MG-63 OS cell line. The present study assessed 14 botanical extracts. The results demonstrated that, of the 14 botanical extracts, resveratrol markedly inhibited the protein expression of $\beta$-catenin, whereas no pronounced changes were observed in the remaining 13 botanical extracts (Fig. 1). Therefore, it was hypothesized that resveratrol may be used as a potential drug for the treatment of OS.

Resveratrol inhibits the proliferation of human MG-63 OS cells. In order to confirm the hypothesis that resveratrol may benefit OS treatment, a CCK-8 assay was performed to detect the proliferation rate of the human MG-63 OS cells treated 


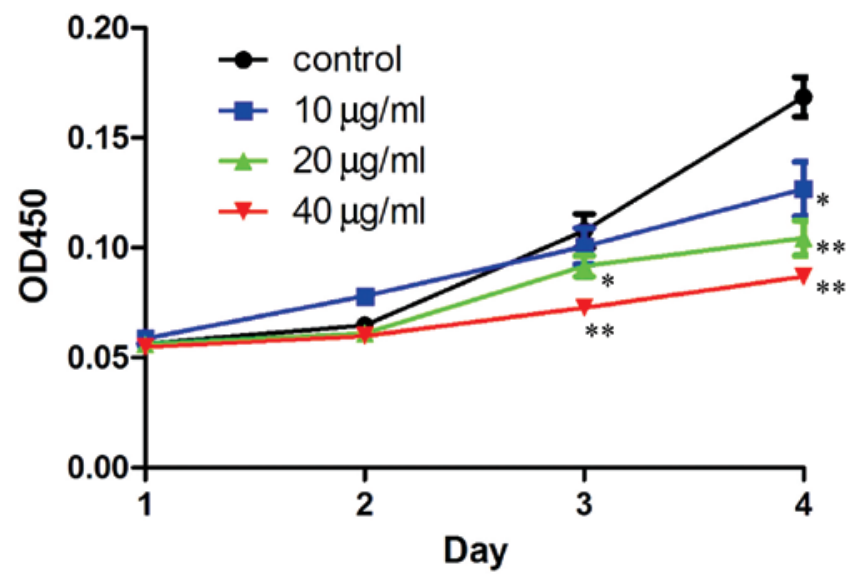

Figure 2. Effect of resveratrol on the proliferation rate of the human MG-63 osteosarcoma cell line. Resveratrol was added to cells at 10,20 and $40 \mu \mathrm{g} / \mathrm{ml}$, and the effect on cell proliferation was assessed over 4 days using a cell counting kit- 8 assay. The $\mathrm{OD}_{450}$ value is expressed as the mean \pm standard deviation. ${ }^{*} \mathrm{P}<0.05$ and ${ }^{* *} \mathrm{P}<0.01$ vs. blank control. OD, optical density.

A

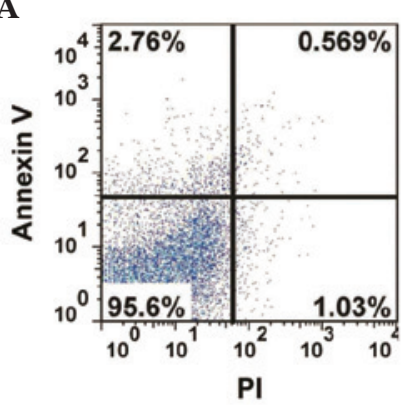

$\mathbf{E}$

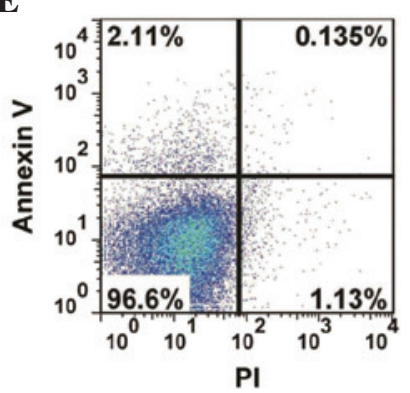

B

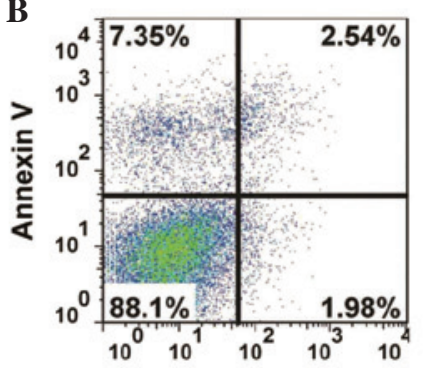

PI

F

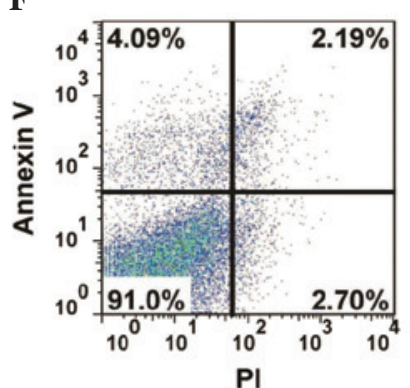

C

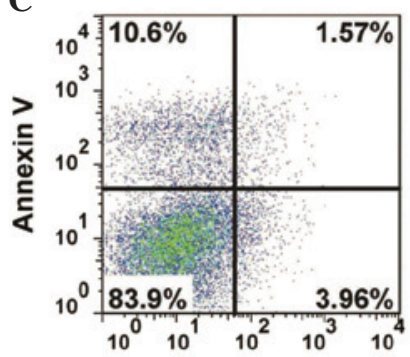

PI

G

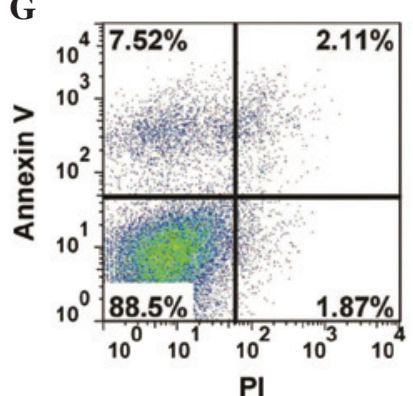

D

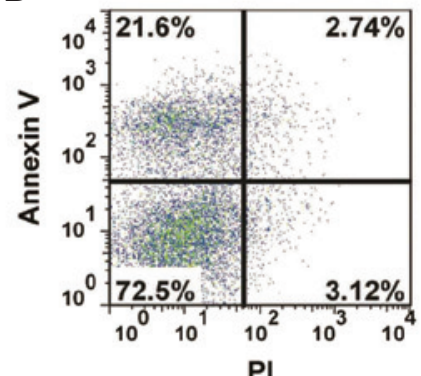

H

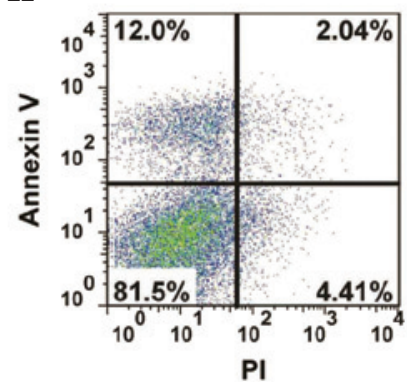

Figure 3. Analysis of apoptosis in the human MG-63 osteosarcoma cell line following treatment with resveratrol alone or in combination with the GSK3 $\beta$ inhibitor, chir99021. Following drug treatment for $72 \mathrm{~h}$, the cells were labeled with annexin V and PI and the apoptosis was detected using flow cytometry. (A) $0 \mu \mathrm{g} / \mathrm{ml}$, (B) $10 \mu \mathrm{g} / \mathrm{ml}$, (C) $20 \mu \mathrm{g} / \mathrm{ml}$ and (D) $40 \mu \mathrm{g} / \mathrm{ml}$ resveratrol, (E) dimethyl sulfoxide, (F) $3 \mu \mathrm{M}$ chir99021+10 $\mu \mathrm{g} / \mathrm{ml}$, (G) $3 \mu \mathrm{M} \mathrm{chir} 99021+20 \mu \mathrm{g} / \mathrm{ml}$, (H) $3 \mu \mathrm{M}$ chir99021+40 $\mu \mathrm{g} / \mathrm{ml}$ resveratrol. Upper left quadrant, apoptotic cells; upper right, dead and late apoptotic cells; lower left, living cells; lower right, mechanically injured cells. PI, propidium iodide.

with resveratrol. The results demonstrated that resveratrol significantly $(\mathrm{P}=0.043,20 \mu \mathrm{g} / \mathrm{ml}$ treatment group, 3 days; $\mathrm{P}=0.006,40 \mu \mathrm{g} / \mathrm{ml}$ treatment group, 3 days; $\mathrm{P}=0.037,10 \mu \mathrm{g} / \mathrm{ml}$ treatment group, 4 days; $\mathrm{P}=0.002,20 \mu \mathrm{g} / \mathrm{ml}$ treatment group, 4 days; $\mathrm{P}=0.0009,40 \mu \mathrm{g} / \mathrm{ml}$ treatment group, 4 days; treatment v.s. control). inhibited the proliferation of the human MG-63 OS cells. Furthermore, the inhibition rate was dose-and time-dependent (Fig. 2).

Analysis of apoptosis. The apoptotic changes in the human MG-63 OS cells treated with resveratrol were determined using flow cytometry. The results revealed that the apoptotic rate of the cells increased significantly $(\mathrm{P}=0.046)$ following $72 \mathrm{~h}$ drug treatment, and the apoptotic rate reached $27.5 \%$ in the group treated with $40 \mu \mathrm{g} / \mathrm{ml}$ resveratrol (Fig. 3D). In the Wnt signaling pathway, GSK3 $\beta$ is a negative regulator, which is involved in the degradation of $\beta$-catenin (26). In the present study, chir99021, an inhibitor of GSK3 $\beta$, was used to inhibit GSK3 $\beta$. Following treatment with resveratrol and chir99021, cell apoptosis was detected using flow cytometry. As shown in Fig. 3, the apoptotic rate decreased markedly, compared with the control groups. These results suggested that resveratrol inhibited the proliferation of the human MG-63 OS cells through the apoptotic pathway.

Immunoblotting and RT-qPCR. To further understand the mechanism underlying the effects of resveratrol, western blotting and RT-qPCR were performed following treatment 
A
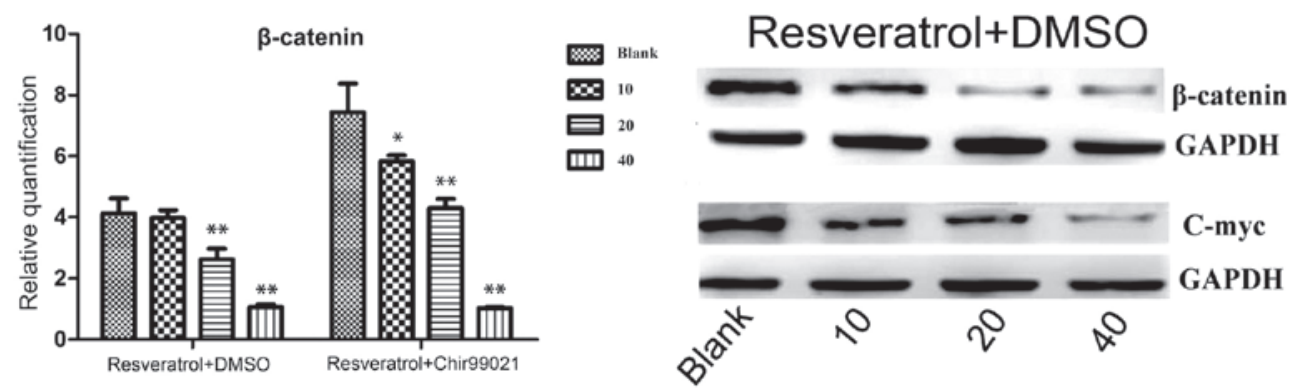

B
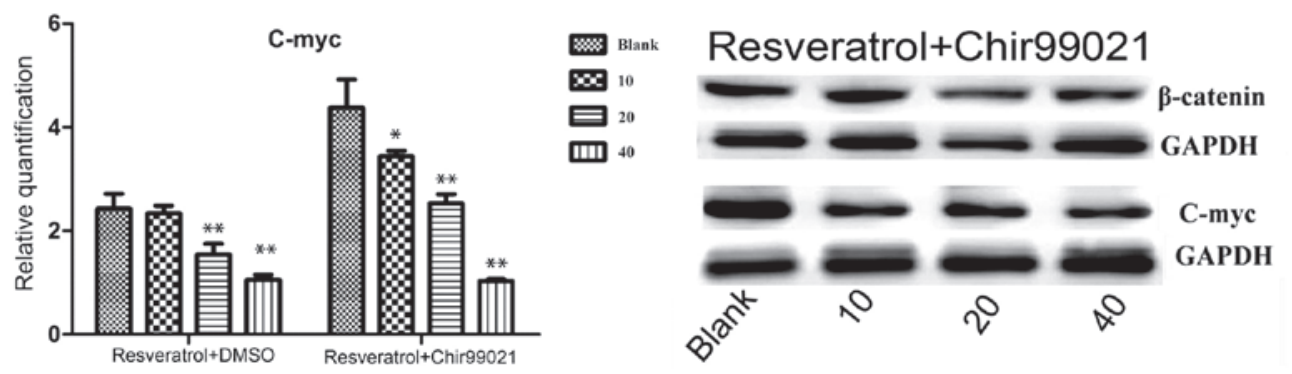

Figure 4. Expression of $\beta$-catenin and its target gene in the human MG-63 osteosarcoma cell line following treatment with resveratrol alone or in combination with the GSK3 $\beta$ inhibitor, chir99021. Following drug treatment for $48 \mathrm{~h}$, reverse transcription-quantitative polymerase chain reaction and western blotting were performed to determine the expression levels of (A) $\beta$-catenin and its target gene (B) c-Myc. The relative expression is expressed as the mean \pm standard deviation. ${ }^{*} \mathrm{P}<0.05$ and ${ }^{* *} \mathrm{P}<0.01$ vs. blank control. DMSO, dimethyl sulfoxide; Blank, untreated control.

with resveratrol alone or combined with chir99021. As shown in Fig. 4, $\beta$-catenin was markedly (mRNA level: $\mathrm{P}=0.003$, $20 \mu \mathrm{g} / \mathrm{ml}$ treatment group; $\mathrm{P}=0.0017,40 \mu \mathrm{g} / \mathrm{ml}$ treatment group; resveratrol + DMSO, treatment v.s. control) downregulated at the protein and mRNA expression levels following treatment with resveratrol, however, the expression of $\beta$-catenin increased following treatment with resveratrol and chir99021. In addition, c-Myc, one of target genes of the Wnt signaling pathway, was also detected. c-Myc was markedly (mRNA level: $\mathrm{P}=0.003,20 \mu \mathrm{g} / \mathrm{ml}$ treatment group; $\mathrm{P}=0.0023$, $40 \mu \mathrm{g} / \mathrm{ml}$ treatment group; resveratrol + DMSO treatment v.s. control) downregulated at the protein and mRNA expression levels following treatment with resveratrol. When the inhibitor, chir99021, was added, the expression of c-Myc increased.

\section{Discussion}

Although OS is a rare type of primary malignancy, it is ranked among the leading causes of cancer-associated mortality in the pediatric age group $(2,27)$. With the introduction of chemotherapy, the 5-year-survival rate has increased to $60-70 \%$, however, 30 years have passed since the method was introduced, and the development of novel therapeutic drugs for the treatment of OS has been slow (28). Therefore, the development of novel drugs for the treatment of OS is urgently required to overcome this bottleneck. The present study aimed to screen for a novel therapeutic drug for the treatment of OS using high content screening and reveal its functional mechanism.

A mutation in $\beta$-catenin, one of the key members of the Wnt signaling pathway, has been identified in a variety of types of cancer (11,29-31). Therefore, the present study used $\beta$-catenin as a drug target and performed high content screening to identify novel drugs against the human MG-63 OS cell line. As shown in Fig. 1, the botanical extract, resveratrol, markedly downregulated the expression of $\beta$-catenin at the protein level. A previous study demonstrated that the aberrant expression of $\beta$-catenin activates its numerous downstream targets, a number of which are associated with cancer progression (32). Therefore, the present study hypothesized that resveratrol may inhibit the proliferation of human MG-63 OS cells. Based on this hypothesis, the proliferation rate of human MG-63 OS cells treated with resveratrol was assessed. The results were consistent with the hypothesis that resveratrol can significantly $(\mathrm{P}<0.05)$ inhibit proliferation of the human MG-63 OS cell line. The present study subsequently aimed to further understand the underlying mechanism. Aberrant activation of the Wnt signaling pathway can initiate the expression of numerous downstream genes, including c-Myc (33), cyclin D1 (34) and survivin (35). Survivin is an inhibitor of apoptosis, therefore, the apoptosis of human MG-63 OS cells treated with resveratrol was assessed using flow cytometry. As shown in Fig. 3, the apoptotic ratio markedly increased following treatment with resveratrol. In parallel experiments, resveratrol and chir99021, an inhibitor of GSK $3 \beta$ that can activate the Wnt signaling pathway, were added and the apoptotic response of the cells was analyzed. The results demonstrated that the apoptotic ratio was markedly reduced, compared with resveratrol-only group. These data suggested that resveratrol inhibited the proliferation of human MG-63 OS cell by inhibiting the canonical Wnt signaling pathway. To further confirm this conclusion, western blotting and RT-qPCR were performed to determine the expression levels of $\beta$-catenin and its target gene, c-Myc. As shown in Fig. 4, the mRNA and protein expression levels of $\beta$-catenin and c-Myc were markedly downregulated. Following the addition of chir99021, the expression levels were increased. This data suggested that resveratrol inhibited the Wnt signaling pathway by downregulating the expression of $\beta$-catenin. 
In conclusion, the present study identified resveratrol as a novel botanical extract, which markedly inhibited the proliferation of human MG-63 OS cells by downregulating the expression of $\beta$-catenin in the Wnt signaling pathway. Although the present study was preliminary, it indicates potential for the treatment of OS in the future. Subseqeunt experiments in animal models are required to determine the inhibitory efficiency for OS cells.

\section{Acknowledgements}

This study was supported by the National Natural Foundation of China (grant. no. 60171009).

\section{References}

1. Ottaviani G and Jaffe N: The epidemiology of osteosarcoma. In: Pediatric and Adolescent Osteosarcoma. Jaffe N, Bruland OS and Bielack S (eds). Springer US pp3-pp13, 2010.

2. Botter SM, Neri D and Fuchs B: Recent advances in osteosarcoma. Curr Opin Pharmacol 16: 15-23, 2014.

3. Linabery AM and Ross JA: Trends in childhood cancer incidence in the U.S. (1992-2004). Cancer 112: 416-432, 2008.

4. Allison DC, Carney SC, Ahlmann ER, Hendifar A, Chawla S, Fedenko A, Angeles C and Menendez LR: A meta-analysis of osteosarcoma outcomes in the modern medical era. Sarcoma 2012: 704872, 2012.

5. Logan CY and Nusse R: The Wnt signaling pathway in development and disease. Annu Rev Cell Dev Biol 20: 781-810, 2004.

6. Kinzler KW, Nilbert MC, Su LK, Vogelstein B, Bryan TM, Levy DB, Smith KJ, Preisinger AC, Hedge P and McKechnie D: Identification of FAP locus genes from chromosome $5 q 21$. Science 253: 661-665, 1991.

7. Nishisho I, Nakamura Y, Miyoshi Y, Miki Y, Ando H, Horii A, Koyama K, Utsunomiya J, Baba S and Hedge P: Mutations of chromosome 5q21 genes in FAP and colorectal cancer patients. Science 253: 665-669, 1991.

8. Giles RH, van Es JH and Clevers H: Caught up in a Wnt storm: Wnt signaling in cancer. Biochim Biophys Acta 1653: 1-24, 2003

9. Satoh S, Daigo Y, Furukawa Y, Kato T, Miwa N, Nishiwaki T, Kawasoe T, Ishiguro H, Fujita M, Tokino T, et al: AXIN1 mutations in hepatocellular carcinomas, and growth suppression in cancer cells by virus-mediated transfer of AXIN1. Nat Genet 24: 245-250, 2000.

10. Clevers H: Wnt/beta-catenin signaling in development and disease. Cell 127: 469-480, 2006.

11. Morin PJ, Sparks AB, Korinek V, Barker N, Clevers H, Vogelstein B and Kinzler KW: Activation of beta-catenin-Tcf signaling in colon cancer by mutations in beta-catenin or APC. Science 275: 1787-1790, 1997.

12. Korinek V, Barker N, Morin PJ, van Wichen D, de Weger R, Kinzler KW, Vogelstein B and Clevers H: Constitutive transcriptional activation by a beta-catenin-Tcf complex in APC-/-colon carcinoma. Science 275: 1784-1787, 1997.

13. MacDonald BT, Tamai K and He X: Wnt/beta-catenin signaling: Components, mechanisms, and diseases. Dev Cell 17: 9-26, 2009.

14. He TC, Sparks AB, Rago C, Hermeking H, Zawel L, da Costa LT, Morin PJ, Vogelstein B and Kinzler KW: Identification of c-MYC as a target of the APC pathway. Science 281: 1509-1512, 1998.

15. Tetsu $\mathrm{O}$ and McCormick F: Beta-catenin regulates expression of cyclin D1 in colon carcinoma cells. Nature 398: 422-426, 1999.
16. Roose J, Huls G, van Beest M, Moerer P, van der Horn K, Goldschmeding R, Logtenberg $\mathrm{T}$ and Clevers H: Synergy between tumor suppressor APC and the beta-catenin-Tcf4 target Tcf1. Science 285: 1923-1926, 1999.

17. Jho EH, Zhang T, Domon C, Joo CK, Freund JN and Costantini F: Wnt/beta-catenin/Tef signaling induces the transcription of Axin2, a negative regulator of the signaling pathway. Mol Cell Biol 22: 1172-1183, 2002

18. Ng TL, Gown AM, Barry TS, Cheang MC, Chan AK, Turbin DA, Hsu FD, West RB and Nielsen TO: Nuclear beta-catenin in mesenchymal tumors. Mod Pathol 18: 68-74, 2005.

19. Jang M, Cai L, Udeani GO, et al: Cancer chemopreventive activity of resveratrol, a natural product derived from grapes. Science 275: 218-220, 1997.

20. Joe AK, Liu H, Suzui M, Vural ME, Xiao D and Weinstein IB: Resveratrol induces growth inhibition, S-phase arrest, apoptosis, and changes in biomarker expression in several human cancer cell lines. Clin Cancer Res 8: 893-903, 2002.

21. Athar M, Back JH, Tang X, et al: Resveratrol: A review of preclinical studies for human cancer prevention. Toxicol Appl Pharmacol 224: 274-283, 2007.

22. Alkhalaf M and Jaffal S: Potent antiproliferative effects of resveratrol on human osteosarcoma SJSA1 cells: Novel cellular mechanisms involving the ERKs/p53 cascade. Free Radic Biol Med 41: 318-325, 2006.

23. Alkhalaf M, El-Mowafy A, Renno W, Rachid O, Ali A and Al-Attyiah R: Resveratrol-induced apoptosis in human breast cancer cells is mediated primarily through the caspase-3-dependent pathway. Arch Med Res 39: 162-168, 2008.

24. He N and Zhang Z: Baicalein suppresses the viability of MG-63 osteosarcoma cells through inhibiting c-MYC expression via Wnt signaling pathway. Mol Cell Biochem 405: 187-196, 2015.

25. Livak KJ and Schmittgen TD: Analysis of relative gene expression data using real-time quantitative PCR and the 2(-Delta Delta C(T)) Method. Methods 25: 402-408, 2001.

26. Nakamura T, Hamada F, Ishidate T, Ishidate T, Anai K, Kawahara K, Toyoshima K and Akiyama T: Axin, an inhibitor of the Wnt signalling pathway, interacts with beta-catenin, GSK-3beta and APC and reduces the beta-catenin level. Genes Cells 3: 395-403, 1998.

27. Luetke A, Meyers PA, Lewis I and Juergens H: Osteosarcoma treatment-Where do we stand? A state of the art review. Cancer Treat Rev 40: 523-532, 2014.

28. Yamamoto $\mathrm{N}$ and Tsuchiya $\mathrm{H}$ : Chemotherapy for osteosarcoma-where does it come from? What is it? Where is it going? Expert Opin Pharmacother 14: 2183-2193, 2013.

29. Miyaki M, Iijima T, Kimura J, Yasuno M, Mori T, Hayashi Y, Koike M, Shitara N, Iwama T and Kuroki T: Frequent mutation of beta-catenin and APC genes in primary colorectal tumors from patients with hereditary nonpolyposis colorectal cancer. Cancer Res 59: 4506-4509, 1999.

30. Morin PJ: $\beta$-catenin signaling and cancer. Bioessays 21: 1021-1030, 1999.

31. Polakis P: Wnt signaling and cancer. Genes Dev 14: 1837-1851, 2000.

32. Polakis P: The oncogenic activation of beta-catenin. Curr Opin Genet Dev 9: 15-21, 1999.

33. He T-C, Sparks AB, Rago C, Hermeking H, Zawel L, da Costa LT, Morin PJ, Vogelstein B and Kinzler KW: Identification of c-MYC as a target of the APC pathway. Science 281: 1509-1512, 1998.

34. Hedberg Y, Ljungberg B, Roos G and Landberg G: Expression of cyclin D1, D3, E and p27 in human renal cell carcinoma analysed by tissue microarray. Br J Cancer 88: 1417-1423, 2003.

35. Yang LQ, Fang DC, Wang RQ and Yang SM: Effect of NF-kappaB, survivin, Bcl-2 and Caspase 3 on apoptosis of gastric cancer cells induced by tumor necrosis factor related apoptosis inducing ligand. World J Gastroenterol 10: 22-25, 2004. 